\title{
Differences in the Olfactory Sensitivity of Ceratitis capitata to Headspace of Some Host Plants in Relation to Sex, Mating Condition and Population
}

\author{
Giorgia Sollai * ${ }^{(\mathbb{D}}$, Paolo Solari $(\mathbb{D}$ and Roberto Crnjar \\ Department of Biomedical Sciences, Section of Physiology, University of Cagliari, 09042 Monserrato (CA), Italy; \\ solari@unica.it (P.S.); crnjar@unica.it (R.C.) \\ * Correspondence: gsollai@unica.it ; Tel.: +39-070-6754160
}

Received: 25 April 2020; Accepted: 22 May 2020; Published: 24 May 2020

\begin{abstract}
The Mediterranean fruit fly, Ceratitis capitata Wied., is among the most serious pests in horticulture worldwide, due to its high reproductive potential, difficulty of control and broad polyphagy. The aim of this study was to measure-by means of the electroantennogram recordings - the antennal olfactory sensitivity of virgin, mated, male, female, lab-reared and wild C. capitata following stimulation with fruit and leaf headspace of some host-plants: clementine, orange, prickly pear, lemon and apple. The results show that: (a) lab-reared mated males are more sensitive to host-plant fruit and leaf headspace than females, while the opposite was true for wild insects; (b) antennae of wild virgin males were more sensitive than the mated ones, while no difference was observed among lab-reared medflies; (c) lab-reared virgin females were more sensitive than mated ones, while few differences were found within wild medflies; (d) in mated insects, lab-reared males were more sensitive to both host-plant fruits and leaves than the wild ones, while the opposite was found for females. Taken together, these results show that the olfactory sensitivity to host-plant odors differs between virgin and mated and lab-reared and wild flies.
\end{abstract}

Keywords: olfaction; medfly; mating; sex; population

\section{Introduction}

In animals, the ability to identify mating partners, oviposition sites and food sources is strongly influenced by information arising from their chemical senses, olfaction and taste [1-13]. In both vertebrates and invertebrates-chemosensory performance varies among organisms belonging to the same species, and this diversity depends on age, sex, physiological state, diet, population, habitat and genetic factors [14-28]. Insects have developed sophisticated olfactory systems that allow them to detect odorous chemical signals, such as sexual pheromones, aggregation pheromones and food odors. Their olfactory systems consist of olfactory sensory neurons (OSNs) housed in the sensilla of antennae, maxillary palps and ovipositors [29-32]. The odorous molecules penetrate through the cuticular pores inside the sensilla, where they bind to the odorant-binding proteins (OBPs) to be transported to the olfactory receptors (ORs) on the neuronal membrane. Here, they interact with ORs and the chemical information is transformed into a train of action potentials that reaches the antennal lobes- the first region of the central nervous system - where the olfactory information is processed [33-35].

The Mediterranean fruit fly, Ceratitis capitata Wied., is one of the most destructive agricultural insect pests due to its broad polyphagy, biologic potential and the difficulty to control its population [36-38]. Medfly infests more than 350 species of fruits, but in Southern Europe it is mainly attracted by pomaceous (apples and pears) and citrus (oranges) cultures [39-41]. Currently, the techniques in use to control C. capitata populations, such as sterile insect technique (SIT) and mass-trapping, are based 
on species-specific attractants acting on the olfactory system of the insects [42,43]. Previous studies have shown that females are more sensitive to some citrus peel oils and volatile compounds than males [44-47]. Males instead exhibit a stronger preference than females than for the volatile orange flavedo and ginger root oils; exposure to these compounds is believed to increase reproductive success of both sterile and non-sterile males [48-52]. Further, Jang [53,54] reports that mating changes the olfactory preferences of females: in fact, virgin females are more attracted to the male sexual pheromone, while mated ones shift their attention to the odors of molecules that indicate oviposition sites. Finally, laboratory-reared females show a higher sensitivity to alpha-farnesene (one of the major components of male sex pheromone) than wild females [55].

Based on these considerations, the aim of this study was to obtain further knowledge on the olfactory sensitivity of adult insects of $C$. capitata to fruit and leaf headspace of different host-plants in both sexes (males and females), in different physiological states (virgin and mated) and in insects belonging to different populations (laboratory reared and wild).

\section{Materials and Methods}

\subsection{Insects}

All experiments were performed on adult sexually mature (4-6 days old) medflies of $C$. capitata (Wied.) of both sexes obtained from two different populations: a laboratory-reared population (LP) and a wild population (WP). The pupae of LP medflies originated from a colony at the Dept. of Animal Biology of the University of Pavia (Italy), while the WP pupae (Citrus sinensis) were obtained from orange fruits collected in the spring of 2019 in Sardinia (Italy). The pupae of both populations were reared at the insectary annex of the physiology laboratories (University of Cagliari), under controlled conditions $\left(22 \pm 1{ }^{\circ} \mathrm{C}, 60-70 \%\right.$ relative humidity, $12: 12 \mathrm{~h}$ light:dark cycle) in a climatic chamber. Soon after eclosion, males and females were separated by sex and divided into two groups. In the case of virgin flies the two sexes were kept apart in order to prevent contact, those of the mated group were kept in a common cage to allow mating. Adult flies were fed a mixture of sugar and yeast (4:1) [35] and had free access to fresh water.

\subsection{Electrophysiology}

Recordings were performed on antennae by means of the electroantennogram (EAG) technique [56]. Two glass micropipettes ( $20 \mu \mathrm{m}$ tip diameter) filled with saline solution $\left(\mathrm{NaCl} 0.9 \%, \mathrm{KCl} 0.02 \%, \mathrm{CaCl}_{2}\right.$ $0.02 \%, \mathrm{NaHCO}_{3} 0.01 \%$, final $\mathrm{pH}$ 6.9) [57] were used as reference and recording electrodes in EAG recordings: the former was inserted into the isolated head through the "foramen magnum", while the latter was placed on the distal end of the antennal surface. The antennae, one per fly, were positioned in such a way as to maximize exposure to the stimulus-bearing airflow. Air and odors were delivered by means of an air-stimulus control device (model CS-55, Syntech, Hilversum, The Netherlands) according to Solari et al. [58] and Sollai et al. [59]. All signals were recorded with a high input impedance $\left(10^{15} \Omega\right.$ ) electrometer (WPI, Duo 773$)$, band-pass filtered $(0.1-3 \mathrm{KHz})$, digitized by means of an Axon Digidata 1440A A/D acquisition system (sampling rate $10 \mathrm{KHz}$ ) and stored on $\mathrm{PC}$ for later analysis $[60,61]$. The absolute EAG amplitudes during a 2-s stimulation period were calculated by means of Axoscope 10.0 software $[60,61]$. Physiological variables considered for the experiments were sex, mated or unmated state and population (laboratory reared population: LP; wild population: WP).

\subsection{Stimuli}

Fruit and leaf headspace of orange (Citrus sinensis), prickly pear (Opuntia ficus-indica), lemon (Citrus limon), clementine (Citrus clementina) and apple (Malus domestica) were tested as olfactory stimuli. These stimuli were selected on the basis of observations on medfly crop infestations in Sardinia. Volatiles were extracted from fruits and leaves obtained from organic crops of Southern Sardinia (Italy), as described by Stensmyr et al. [62] and Sollai et al. [63]. Briefly, pieces of fruit pulp or leaves (about 
$200 \mathrm{~g}$ ) were placed in an airtight $0.5 \mathrm{~L}$ glass container with a flow-through device fitted with a Porapak Q filter (150/75 mg, 50/80; Supelco). The filter was placed inside a glass adsorption tube (5 mm Ø) which was inserted into the collection port at the top of the container. Volatiles were collected at room temperature by flushing the system for $12 \mathrm{~h}$ with a purified airflow at $550 \mathrm{~mL} / \mathrm{min}$. Trapped volatiles were eluted from the Porapak $\mathrm{Q}$ tube with $1.5 \mathrm{~mL}$ of dichloromethane $\left(\mathrm{CH}_{2} \mathrm{Cl}_{2}\right)$, which then contained a solution of the isolated volatile compounds. From the concentrated fruit and leaf extract, $50 \mu \mathrm{L}$ of solution was pipetted onto a pleated strip of filter study $(80 \times 5 \mathrm{~mm})[58,59]$. Stimuli were administered in a randomized sequence and a blank interstimulus interval was allowed for a complete receptor repolarization, according to Sollai et al. [25].

In order to prevent evaporation, between test sessions the glass pipettes containing test cartridges were sealed at both ends and stored at $-20{ }^{\circ} \mathrm{C}$. Antennae were randomly chosen (right or left) and were tested with all test stimuli.

Each test was replicated 12 times ( $\mathrm{N}=12$ flies, one antenna/fly).

\subsection{Statistical Analysis}

One-way ANOVA was used to verify the effect of the sex, mating condition or population on the EAG responses towards olfactory stimuli.

Data were checked for the assumptions of normality, homogeneity of variance and sphericity (when applicable). Post hoc comparisons were conducted with LSD Fisher's test, unless the assumption of homogeneity of variance was violated, in which case Duncan's test was used [64-66]. Statistical analyzes were performed using STATISTICA for WINDOWS (version 7.0; StatSoft, Inc, Tulsa, OK, USA). $p$ values $<0.05$ were considered significant.

\section{Results}

Samples of EAG recordings obtained from the antennal olfactory sensilla of both males and females, virgins and mated, laboratory and wild population, in response to fruit and leaf headspace of the following stimuli: orange, prickly pear, lemon, clementine and apple, are shown in Figures 1 and 2, respectively.

The mean values \pm SEM of EAG amplitudes evoked by each stimulus are shown in Figures $3-5$. One-way ANOVA showed a significant effect of sex on the EAG values obtained from the mated medflies in response to all stimuli tested, both in LP (Fruits: $\mathrm{F}_{(1,22)}>11.286, p<0.005$; leaves: $\left.\mathrm{F}_{(1,22)}>20.908, p<0.001\right)$ and WP insects (Fruits: $\mathrm{F}_{(1,22)}>8.9855, p<0.01$; leaves: $\mathrm{F}_{(1,22)}>14.284$, $p<0.005)$. Instead, as for virgin medflies, a significant effect of sex was found only in response to odor of lemon fruit in LP insects $\left(\mathrm{F}_{(1,22)}=4.4638, p=0.046\right)$, the odor of apple fruit in WP insects $\left(\mathrm{F}_{(1,22)}=14.447, p<0.001\right)$ and the odor of clementine leaves in LP insects $\left(\mathrm{F}_{(1,22)}=7.2773, p=0.013\right)$. As shown in Figure 3, post hoc comparisons revealed significant differences in the olfactory sensitivity between males and females of the same population (LP or WP) and physiological state (virgin or mated). In particular, for LP insects: (a) the EAG amplitudes in virgin males were significantly higher than in virgin females in response to lemon fruit ( $p<0.05$; LSD Fisher's test) and leaf headspace of clementine ( $p=0.013$; LSD Fisher's test); (b) antennae of mated males were more sensitive to all tested stimuli than those of mated females (lemon and clementine fruits: $p<0.001$, LSD Fisher's test; orange, prickly pear and apple fruits: $p<0.005$, Duncan's test; leaves: $p<0.001$; LSD Fisher's test). For WP insects, the EAG values in virgin males were significant higher than in virgin females in response to apple fruits ( $p=0.001$; LSD Fisher's test), while the olfactory responses evoked by all stimuli in mated insects were significantly higher in females than in males (fruits: $p<0.01$, LSD Fisher's test; orange, lemon, clementine and apple leaves: $p<0.001$, LSD Fisher's test; prickly pear leaves: $p<0.001$, Duncan's test). These results show that males are, in general, more sensitive than females for LP insects, while the opposite was found for WP-mated insects. 


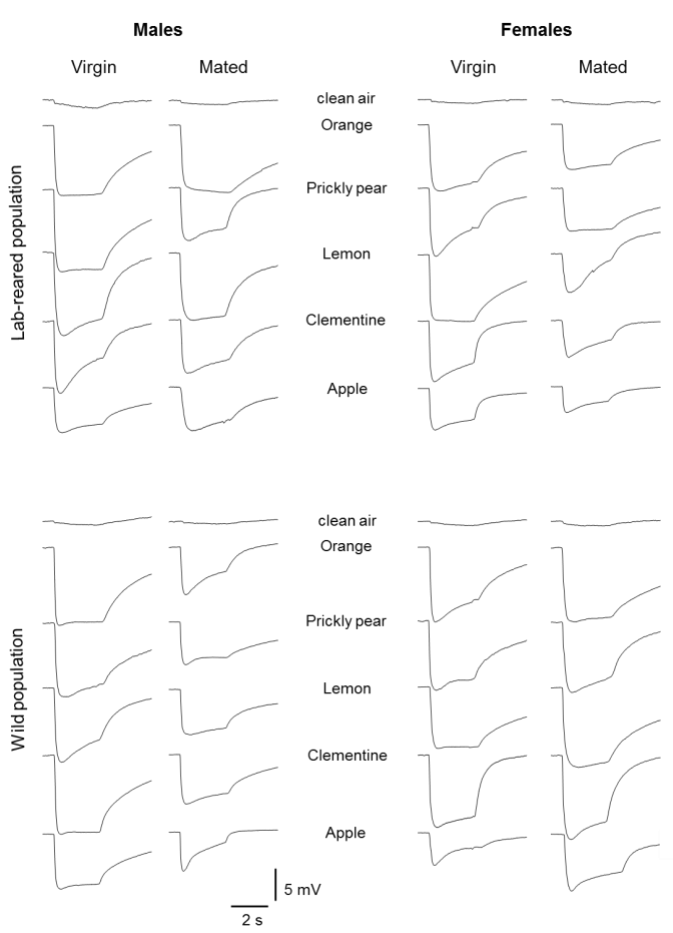

Figure 1. Sample of electroantennogram (EAG) recordings from antennal preparations following stimulation with fruit headspace of orange, prickly pear, lemon, clementine and apple in males and females, virgin and mated insects, belonging to lab-reared or wild population.
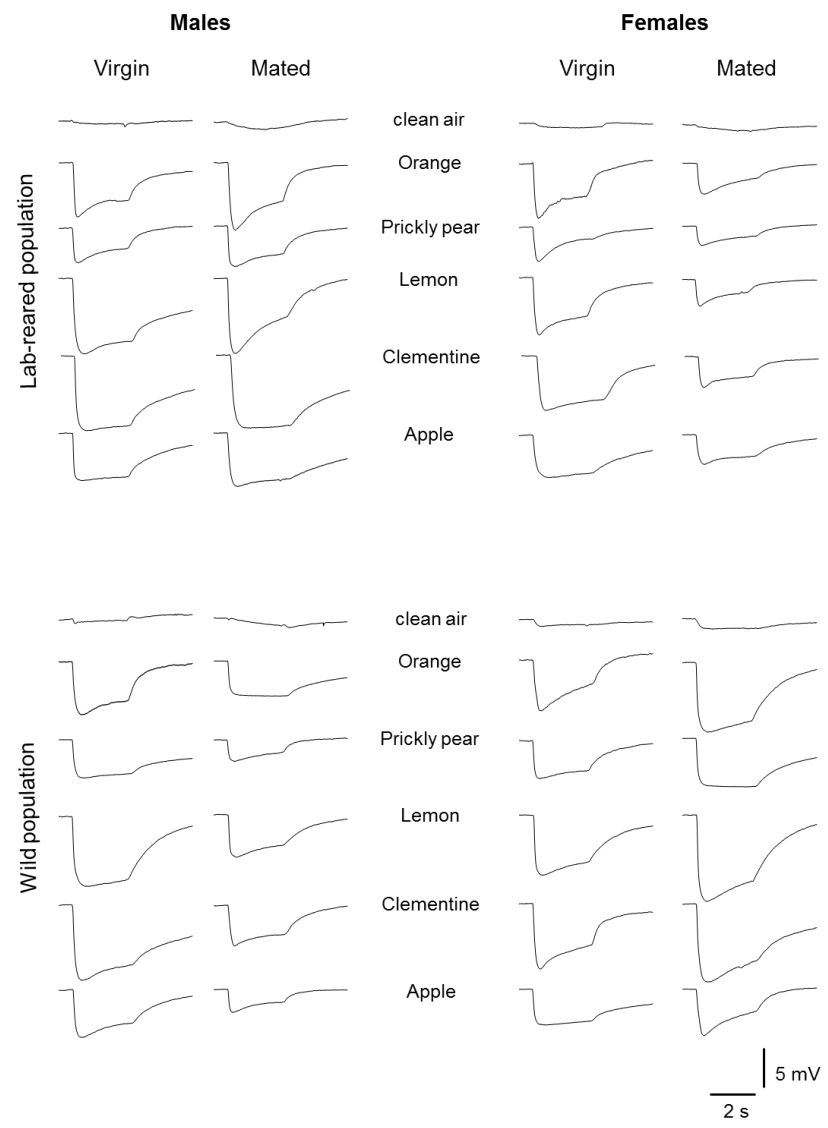

Figure 2. Sample of EAG recordings from antennal preparations following stimulation with leaf headspace of orange, prickly pear, lemon, clementine and apple in males and females, virgin and mated insects, belonging to lab-reared or wild population. 

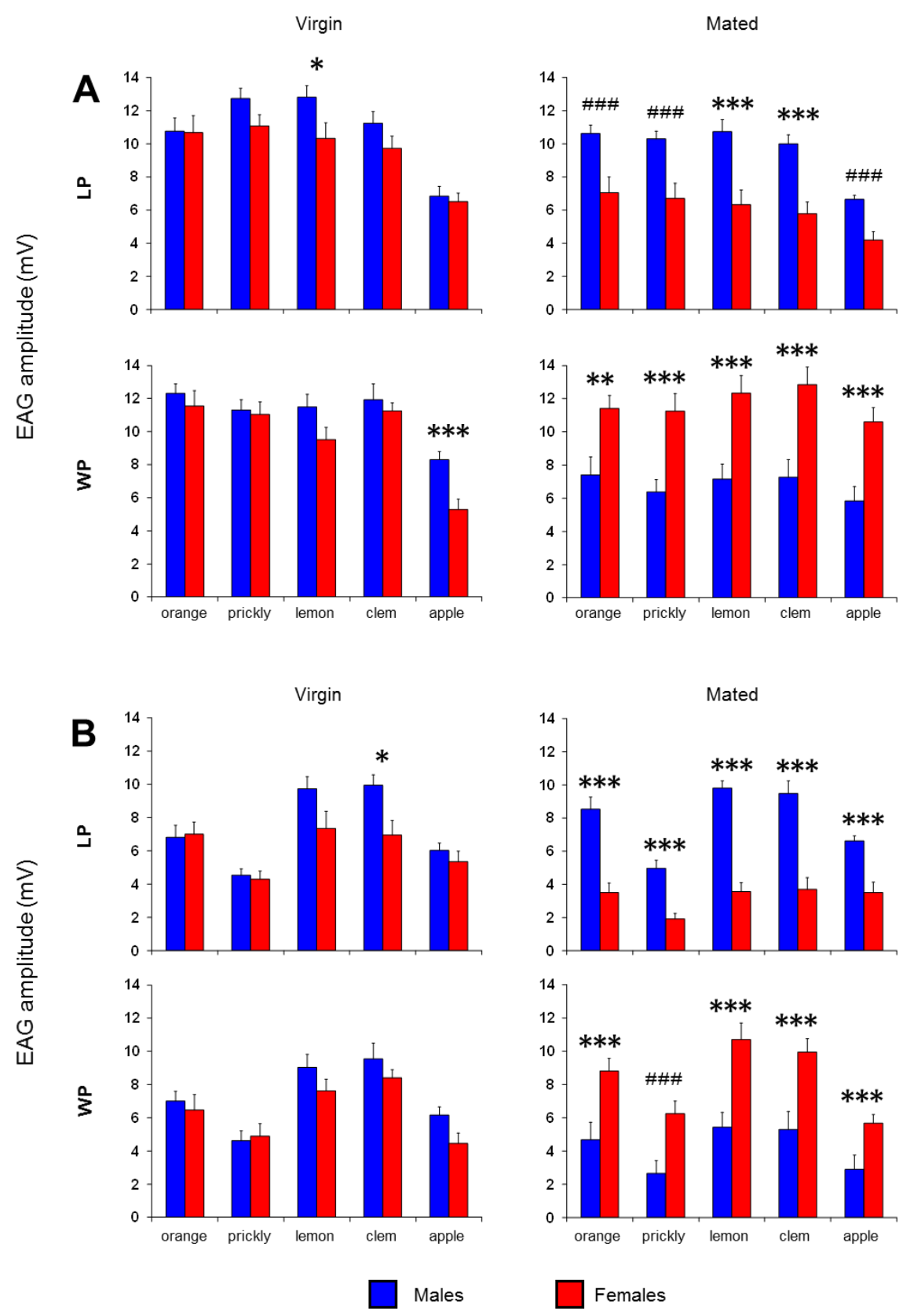

Figure 3. EAG mean amplitude values \pm SEM elicited by stimulation with fruit $(\mathbf{A})$ and leaf $(\mathbf{B})$ headspace of orange, prickly pear, lemon, clementine and apple in both males and females. LP-lab-reared population; WP-wild population. $\mathrm{N}=12$ antennae (1 antenna/medfly). Symbols indicate significant differences between the sexes. LSD Fisher's test: ${ }^{*}-p<0.05,{ }^{* *}-p<0.01,{ }^{* * *}-p<0.005$. Duncan test: $\# \#$ _ $p<0.005$.

ANOVA revealed also a significant effect of the mating condition on the EAG amplitudes recorded in response to all olfactory stimuli from the antennae of LP females (Fruits: $\mathrm{F}_{(1,22)}>6.9093, p<0.02$; leaves: $\left.\mathrm{F}_{(1,22)}>4.4952, p<0.05\right)$, of WP males (Fruits: $\mathrm{F}_{(1,22)}>5.6214, p<0.05$; leaves: $\mathrm{F}_{(1,22)}>5.9663$, $p<0.05)$ and only in response to the odor of lemon $\left(\mathrm{F}_{(1,22)}=4.2894, p=0.039\right)$ and apple fruits $\left(\mathrm{F}_{(1,22)}=24.876, p<0.001\right)$, of orange $\left(\mathrm{F}_{(1,22)}=4.8365, p=0.039\right)$ and lemon leaves $\left(\mathrm{F}_{(1,22)}=4.7851\right.$, $p=0.039$ ) for WP females. As shown in Figure 4, for males, the EAG amplitudes of virgins were significantly higher than those of mated insects in response to all stimuli for WP insects (fruit headspaces: $p<0.05$, LSD Fisher's test; orange, lemon, clementine and apple leaves: $p<0.05$, LSD Fisher's test; prickly pear leaves: $p<0.01$, Duncan's test) and only in response to prickly pear fruit for LP insects 
( $p=0.004$; LSD Fisher's test). For LP females, the EAG responses were higher in virgins than in mated insects (fruits: $p<0.05$, LSD Fisher's test; orange, prickly pear, clementine and apple leaves: $p<0.05$, LSD Fisher's test; lemon leaves: $p<0.005$, Duncan's test), while the opposite was found for the WP females in response to lemon and apple fruits ( $p<0.05$; LSD Fisher's test) and to orange and lemon leaves ( $p<0.05$; LSD Fisher's test).
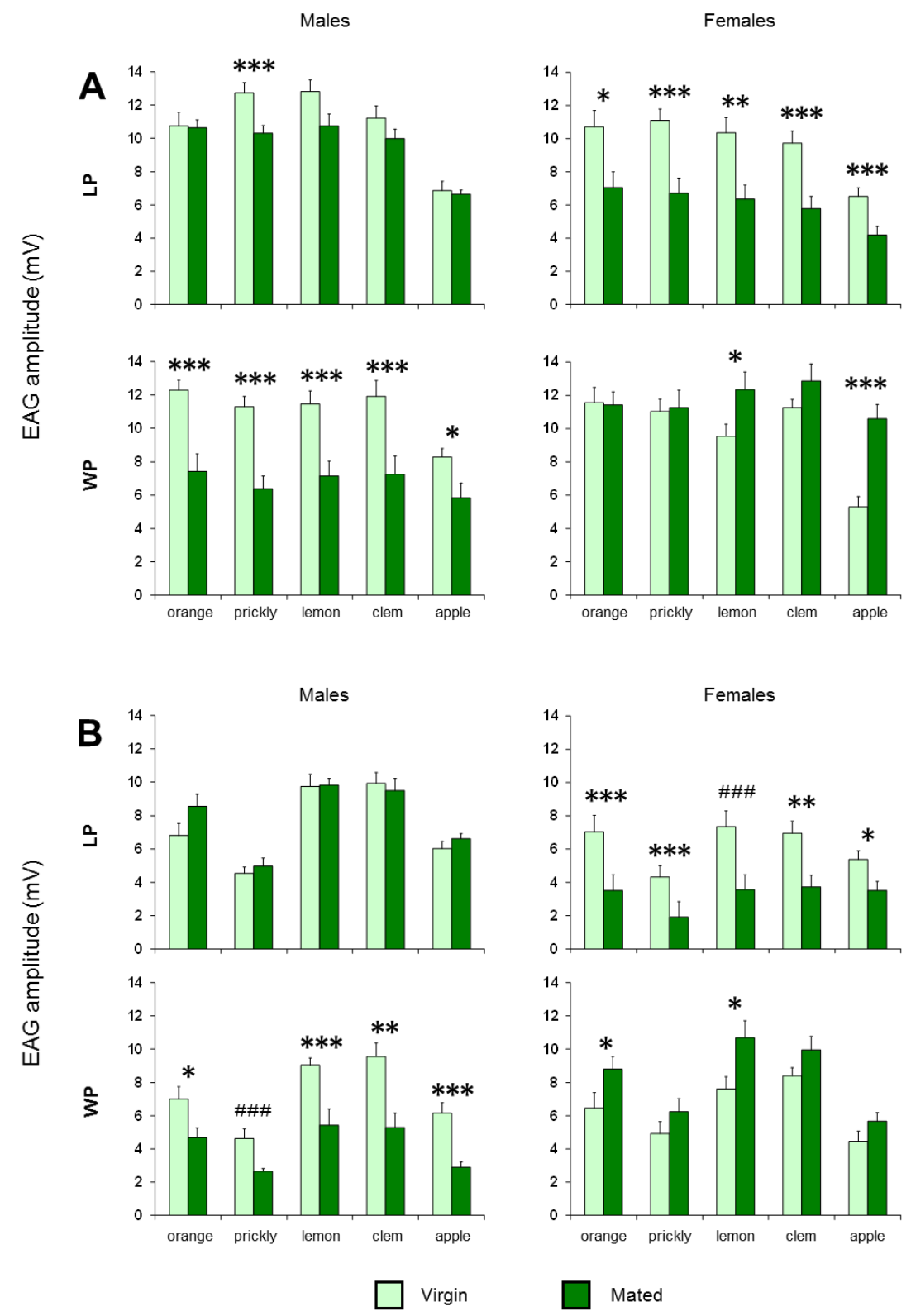

Figure 4. The EAG mean amplitude values \pm SEM elicited by stimulation with fruit (A) and leaf (B) headspace of orange, prickly pear, lemon, clementine and apple in both virgin and mated insects. LP-lab-reared population; WP-wild population; $\mathrm{N}=12$ antennae ( 1 antenna/medfly). Symbols indicate significant differences between the physiological states. LSD Fisher's test: ${ }^{*}-p<0.05$,

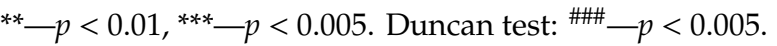

Finally, a significant effect on the EAG responses was found also between the LP and WP insects when the antennae of both mated males and females were stimulated with fruits (Males: $\mathrm{F}_{(1,22)}>5.0598$, $p<0.05$; females: $\left.\mathrm{F}_{(1,22)}>10.705, p<0.005\right)$ and leaves headspace (Males: $\mathrm{F}_{(1,22)}>13.776, p<0.005$; females: $\left.\mathrm{F}_{(1,22)}>7.3647, p<0.02\right)$. In fact, pairwise comparisons revealed significant differences between LP and WP insects of same sex and physiological state (Figure 5). For mated males, the responses 
obtained in LP insects were higher than in WP insects for all olfactory stimuli (fruits: $p<0.05$, LSD Fisher's test; orange, lemon, clementine and apple leaves: $p<0.001$, LSD Fisher's test; prickly pear leaves: $p<0.001$, Duncan's test), except in response to apple fruits ( $p>0.05$; LSD Fisher's test). Instead, for mated females, the responses obtained in WP insects were higher than in LP insects for all olfactory stimuli (fruits: $p<0.005$, LSD Fisher's test; orange, lemon, clementine and apple leaves: $p<0.01$, LSD Fisher's test; prickly pear leaves: $p<0.001$, Duncan's test). No difference was found between the two populations for virgin males and females ( $p>0.05$; LSD Fisher's test).
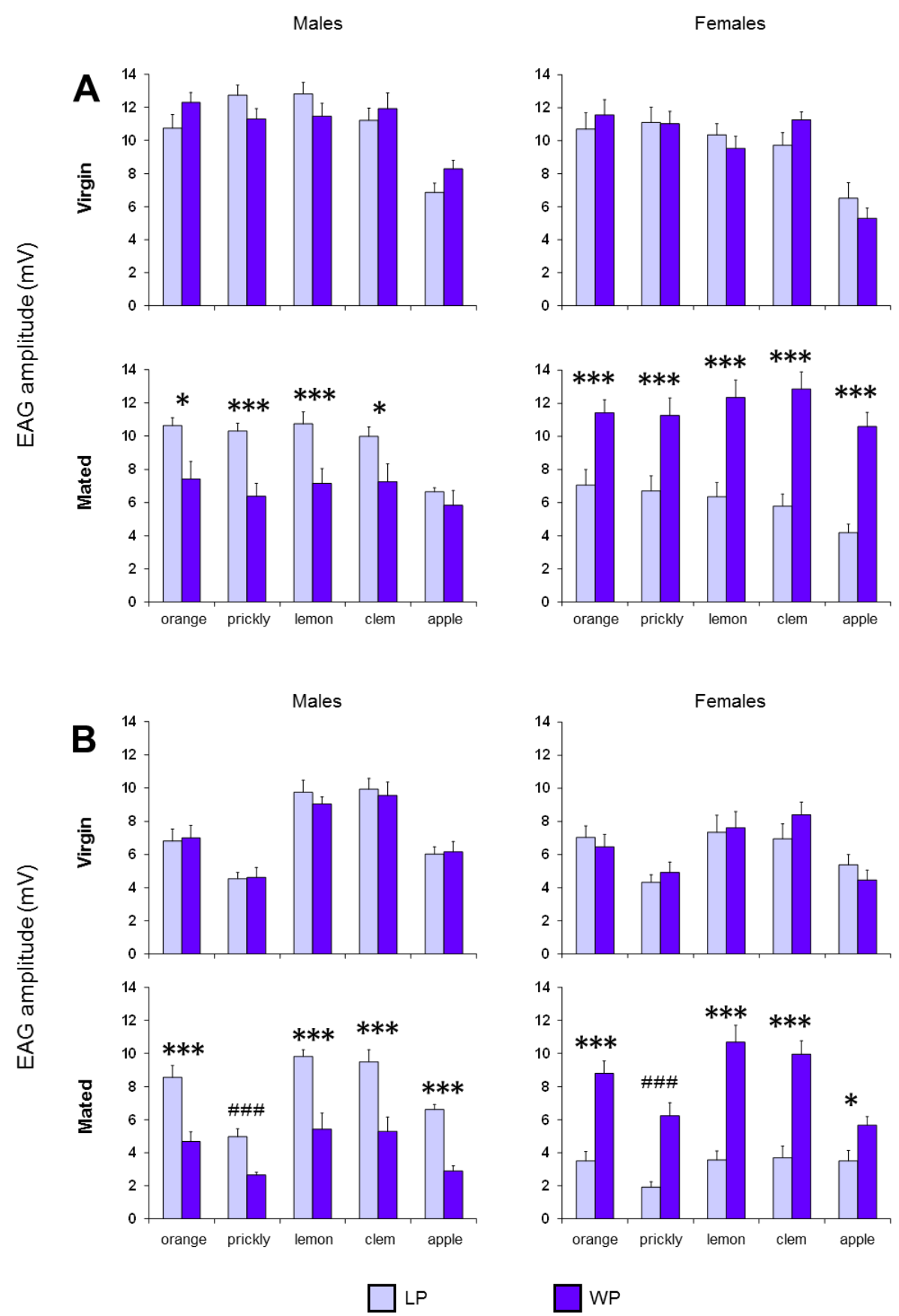

Figure 5. The EAG mean amplitude values \pm SEM elicited by stimulation with fruit (A) and leaf (B) headspace of orange, prickly pear, lemon, clementine and apple in both LP and WP insects. N = 12 antennae ( 1 antenna/medfly). Symbols indicate significant differences between the populations. LSD

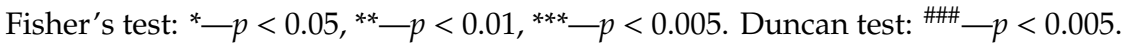




\section{Discussion}

Since the process of locating and recognizing a partner for mating and host plants for oviposition $[25,67]$ is strongly conditioned by the information coming from the olfactory system, the main goal of this study was to evaluate whether the olfactory sensitivity of adult insects of C. capitata towards the complex odor of fruits and leaves of some host-plants depends on sex (males or females), the physiological state (virgins or mated) and the population considered (LP or WP). The results we obtained show that both males and females do present an olfactory sensitivity for all tested stimuli, thus emphasizing that the complex odor of host-plant fruits and leaves is important for both sexes. In particular, the results show that there are no differences between the sexes when considering virgin insects, for both LP and WP populations, while, among mated insects, LP females are less responsive than LP males and that WP males are less responsive than WP females, when the antennae were stimulated with the headspace of both host-plant fruits and of leaves. These results are in agreement with the functional role that olfactory sensitivity for host-plant odors plays in both sexes. In fact, males look for host plants where they can induce lekking to attract females for mating, while females visit host plants with the aim of copulating and finding suitable sites for oviposition $[44,68,69]$. The lack of differences between males and females in the EAG responses to host-plant odors has also been reported in other insects such as Rhagoletis pomonella, Dacus dorsalis and Iragoides fasciata [70-72].

Plant volatile compounds are used by insects as signals for the identification of suitable habitats for mating or oviposition [72-74]. This concept is in agreement with the results we obtained on olfactory sensitivity of insects in relation to their physiological state. We found that the EAG responses to fruits and leaves of host plants are higher in virgin males than mated ones among WP insects, while no difference was found in LP males in relation to physiological state. The high sensitivity of virgin males seems to be linked to the fact that sexually mature males aggregate on the leaves of host plants to form a lekking, that is, a grouping of males that emit the sexual pheromone to attract females for mating [75-77]. Likewise, it has been reported that exposure of males to the odor of ginger root oil, orange fruit or alpha-copaene (one of the citrus-odor volatiles) increases their reproductive success [49-52]. Instead, since males need a resting period to recover energy after mating, this could reduce olfactory sensitivity as a mechanism to restore energy reserves [67]. This idea also seems to be supported by the fact that WP-mated males show a lower sensitivity than LP mated males to all tested stimuli, suggesting that in the field activities such as sexual recall, courtship and mating require a greater energy expenditure than the insects reared in the laboratory, inside confined cages where the females are present in large number. As for females, instead, the results showed a higher sensitivity to all tested olfactory stimuli in LP virgins than mated LPs and no difference between WP females in relation to mating. Sexually mature females are attracted to host plants for two different reasons: on one hand, to visit the lek and choose a partner for mating and on the other to find a suitable site for oviposition $[18,53,54]$. As for the results relating to the effect of the population type (LP or WP), no difference was found among virgin females; on the contrary, among mated females, the responses obtained from antennae of WP females were significantly higher than those recorded from the LP ones. By considering that females drastically change their interest after mating, shifting their attention from partner research to odors of host plants where they can oviposit $[18,53,54]$, we can speculate that the pressure for the search for an oviposition site is greater for wild females than for lab-reared ones, which readily have access to a suitable site to lay eggs. Instead, ovipositing wild females need to find the host plant among many other non-hosts and then a high olfactory sensitivity towards the odors that signal the presence of oviposition sites becomes particularly important.

In conclusion, since the physiological mechanisms that govern the reproductive success of medflies, both in terms of mating and oviposition, are strongly conditioned by the information coming from the chemosensory input, the fact of gaining a better knowledge on the olfactory sensitivity of $C$. capitata, in particular how it varies in relation to sex, physiological status and population, would help in the choice of species-specific attractants to be used in the current techniques of mass capture of medflies. 
Author Contributions: Conceptualization, G.S. and R.C.; methodology, G.S., P.S. and R.C.; validation, G.S., P.S. and R.C.; formal analysis, G.S.; investigation, G.S.; resources, G.S. and R.C.; data curation, G.S.; writing-original draft preparation, G.S.; writing-review \& editing, G.S., P.S. and R.C.; visualization, R.C. and G.S.; supervision, G.S. and R.C.; project administration, G.S. and R.C.; funding acquisition, G.S. and R.C. All authors have read and agreed to the published version of the manuscript.

Funding: This study was supported by a grant from the University of Cagliari (Fondo Integrativo per la Ricerca, FIR 2018-2019).

Acknowledgments: We are grateful to Marco Melis, Dept. of Biomedical Sciences, University of Cagliari, for his technical assistance.

Conflicts of Interest: The authors declare no conflict of interest.

\section{References}

1. Dethier, V.G. The Hungry Fly; Harvard University Press: Cambridge, MA, USA, 1976.

2. Merivee, E.; Ploomi, A.; Rahi, M.; Bresciani, J.; Ravn, H.P.; Luik, A.; Sammelselg, V. Antennal sensilla of the ground beetle Bembidion properans Steph. (Coleoptera, Carabidae). Micron 2002, 33, 429-440. [CrossRef]

3. Masala, C.; Solari, P.; Sollai, G.; Crnjar, R.; Liscia, A. Clonidine effects on protein and carbohydrate electrophysiological responses of labellar and tarsal sensilla in Phormia regina. J. Insect Physiol. 2008, 54, 1193-1199. [CrossRef]

4. Masala, C.; Solari, P.; Sollai, G.; Crnjar, R.; Liscia, A. Transduction mechanism(s) of Na-saccharin in the blowfly Protophormia terraenovae: Evidence for potassium and calcium conductance involvement. J. Comp. Physiol. A 2009, 195, 1141-1151. [CrossRef] [PubMed]

5. Yarmolinsky, D.A.; Zuker, C.S.; Ryba, N.J.P. Common sense about taste: From mammals to insects. Cell 2009, 139, 234-244. [CrossRef] [PubMed]

6. Solari, P.; Masala, C.; Falchi, A.M.; Sollai, G.; Liscia, A. The sense of water in the blowfly Protophormia terraenovae. J. Insect Physiol. 2010, 56, 1825-1833. [CrossRef] [PubMed]

7. Zhang, H.J.; Faucher, C.P.; Anderson, A.; Berna, A.Z.; Trowell, S.; Chen, Q.M.; Xia, Q.Y.; Chyb, S. Comparisons of contact chemoreception and food acceptance by larvae of polyphagous Helicoverpa armigera and oligophagous Bombyx mori. J. Chem. Ecol. 2013, 39, 1070-1080. [CrossRef]

8. Walker, W.B., III; Jacquin-Joly, E.; Hill, S.R. Functional characterization of insect chemoreceptors: Receptivity range, expression and evolution. Front. Ecol. Evol. 2016, 4, 37. [CrossRef]

9. Biolchini, M.; Murru, E.; Anfora, G.; Loy, F.; Banni, S.; Crnjar, R.; Sollai, G. Fat storage in Drosophila suzukii is influenced by different dietary sugars in relation to their palatability. PLoS ONE 2017, 12, e0183173. [CrossRef]

10. Lebreton, S.; Borrero-Echeverry, F.; Gonzalez, F.; Solum, M.; Wallin, E.; Hedenström, E.; Hansson, B.S.; Gustavsson, A.; Bengtsson, M.; Birgersson, G.; et al. A Drosophila female pheromone elicits species-specific long-range attraction via an olfactory channel with dual specificity for sex and food. BMC Biol. 2017, 15, 88. [CrossRef]

11. Sollai, G.; Biolchini, M.; Loy, F.; Solari, P.; Crnjar, R. Taste input from tarsal sensilla is related to egg-laying behavior in Papilio hospiton. Entomol. Exp. Appl. 2017, 165, 38-49. [CrossRef]

12. Sollai, G.; Biolchini, M.; Crnjar, R. Taste sensitivity and divergence in host plant acceptance between adult female and larvae of Papilio hospiton. Insect Sci. 2018, 25, 809-822. [CrossRef] [PubMed]

13. Corda, G.; Solari, P.; Dettori, M.A.; Fabbri, D.; Delogu, G.; Crnjar, R.; Sollai, G. Association between olfactory sensitivity and behavioral responses of Drosophila suzukii to naturally occurring volatile compounds. Arch. Ins. Biochem. Physiol. 2020, e2169. [CrossRef] [PubMed]

14. Wells, D.L.; Hepper, P.G. Directional tracking in the domestic dog, Canis familiaris. Appl. Anim. Behav. Sci. 2003, 84, 297-305. [CrossRef]

15. Laska, M.; Bautista, R.M.; Hofelmann, D.; Sterlemann, V.; Salazar, L.T. Olfactory sensitivity for putrefaction-associated thiols and indols in three species of non-human primate. J. Exp. Biol. 2007, 210, 4169-4178. [CrossRef]

16. Lemmen, J.; Evenden, M. Peripheral and behavioral plasticity of pheromone response and its hormonal control in a long-lived moth. J. Exp. Biol. 2009, 212, 2000-2006. [CrossRef] 
17. Ferdenzi, C.; Roberts, S.C.; Schirmer, A.; Delplanque, S.; Cekic, S.; Porcherot, C.; Cayeux, I.; Sander, D.; Grandjean, D. Variability of affective responses to odors: Culture, gender, and olfactory knowledge. Chem. Senses 2013, 38, 175-186. [CrossRef]

18. Gadenne, C.; Barrozo, R.B.; Anton, S. Plasticity in insect olfaction: To smell or not to smell? Annu. Rev. Entomol. 2016, 61, 317-333. [CrossRef]

19. Martin, F.; Riveron, J.; Alcorta, E. Environmental temperature modulates olfactory reception in Drosophila melanogaster. J. Insect Physiol. 2011, 57, 1631-1642. [CrossRef]

20. Lemmen, J.; Evenden, M. Environmental conditions terminate reproductive diapause and influence pheromone perception in the long-lived moth Caloptilia fraxinella. Physiol. Entomol. 2015, 40, 30-42. [CrossRef]

21. Lemmen, J.K.; Evenden, M.L. The roles of juvenile hormone and biogenic amines on pheromone response plasticity and diapause termination in male Caloptilia fraxinella. Entomol. Exp. Appl. 2016, 158, 184-201. [CrossRef]

22. Tait, G.; Vezzulli, S.; Sassù, F.; Antonini, G.; Biondi, A.; Baser, N.; Sollai, G.; Cini, A.; Tonina, L.; Ometto, L.; et al. Genetic variability in Italian populations of Drosophila suzukii. BMC Genet. 2017, 18, 87. [CrossRef] [PubMed]

23. Lemmen, J.K.; Wist, T.J.; Evenden, M.L. State-dependent plasticity in response to host-plant volatiles in a long-lived moth, Caloptilia fraxinella (Lepidoptera: Gracillariidae). J. Chem. Ecol. 2018, 44, $276-287$. [CrossRef] [PubMed]

24. Sollai, G.; Biolchini, M.; Crnjar, R. Taste receptor plasticity in relation to feeding history in two congeneric species of Papilionidae. J. Insect Physiol. 2018, 107, 41-56. [CrossRef] [PubMed]

25. Sollai, G.; Solari, P.; Crnjar, R. Olfactory sensitivity to major, intermediate and traces components of sex pheromone in Ceratitis capitata is related to mating and circadian rhythm. J. Insect Physiol. 2018, 110, $23-33$. [CrossRef]

26. Clymans, R.; Van Kerckvoorde, V.; Bangels, E.; Akkermans, W.; Alhmedi, A.; De Clercq, P.; Beliën, T.; Bylemans, D. Olfactory preference of drosophila suzukii shifts between fruit and fermentation cues over the season: Effects of physiological status. Insects 2019, 10, 200. [CrossRef]

27. Sollai, G.; Melis, M.; Magri, S.; Usai, P.; Hummel, T.; Tomassini Barbarossa, I.; Crnjar, R. Association between the rs2590498 polymorphism of Odorant-binding Protein (OBPIIa) gene and olfactory performance in healthy subjects. Behav. Brain Res. 2019, 372, 112030. [CrossRef]

28. Tasnin, S.; Merkel, K.; Clarke, A.R. Effects of advanced age on olfactory response of male and female Queensland fruit fly, Bactrocera tryoni (Froggatt) (Diptera: Tephritidae). J. Insect Physiol. 2020, 122, 104024. [CrossRef]

29. Anton, S.; van Loon, J.J.A.; Meijerink, J.; Smid, H.M.; Takken, W.; Rospars, J.P. Central projections of olfactory receptor neurons from single antennal and palpal sensilla in mosquitoes. Arthropod Struct. Dev. 2003, 32, 319-327. [CrossRef]

30. Galizia, C.G.; Roessler, W. Parallel olfactory systems in insects: Anatomy and function. Annu. Rev. Entomol. 2010, 55, 399-420. [CrossRef]

31. Sollai, G.; Solari, P.; Loy, F.; Masala, C.; Crnjar, R.; Liscia, A. Morpho-functional identification of abdominal olfactory receptors in the midge Culicoides imicola. J. Comp. Physiol. A 2010, 196, 817-824. [CrossRef]

32. Martin, F.; Boto, T.; Gomez-Diaz, C.; Alcorta, E. Elements of olfactory recepton in adult Drosophila melanogaster. Anat. Rec. 2013, 296, 1477-1488. [CrossRef] [PubMed]

33. Strausfeld, N.J.; Hildebrand, J.G. Olfactory systems: Common design, uncommon origins? Curr. Opin. Neurobiol. 1999, 9, 634-639. [CrossRef]

34. Galizia, C.G. Olfactory coding in the insect brain: Data and conjectures. Eur. J. Neurosci. 2014, 39, 1784-1795. [CrossRef] [PubMed]

35. Solari, P.; Corda, V.; Sollai, G.; Kreissl, S.; Galizia, C.G.; Crnjar, R. Morphological characterization of the antennal lobes in the Mediterranean fruit fly Ceratitis capitata. J. Comp. Physiol. A 2016, 202, 131-146. [CrossRef] [PubMed]

36. Gasperi, G.; Bonizzoni, M.; Gomulski, L.M.; Murelli, V.; Torti, C.; Malacrida, A.R.; Guglielmino, C.R. Genetic differentiation, gene flow and the origin of infestations of the medfly, Ceratitis capitata. Genetica 2002, 116, 125-135. [CrossRef] 
37. De Meyer, M.; Robertson, M.P.; Peterson, A.T.; Mansell, M.W. Ecological niches and potential geographical distributions of Mediterranean fruit fly (Ceratitis capitata) and Natal fruit fly (Ceratitis rosa). J. Biogeogr. 2008, 35, 270-281. [CrossRef]

38. Diamantidis, A.D.; Carey, J.R.; Nakas, C.T.; Papadopoulos, N.T. Population-specific demography and invasion potential in medfly. Ecol. Evol. 2011, 1, 479-488. [CrossRef]

39. Christenson, L.D.; Foote, R.H. Biology of fruit flies. Annu. Rev. Entomol. 1960, 5, 171-192. [CrossRef]

40. Liquido, N.J.; Cunningham, R.T.; Nakagawa, A. Host plants of Mediterranean fruit fly (Diptera: Tephritidae) on the island of Hawaii (1949-1985 survey). J. Econ. Entomol. 1990, 83, 1863-1878. [CrossRef]

41. Malacrida, A.R.; Gomulski, L.M.; Bonizzoni, M.; Bertin, S.; Gasperi, G.; Guglielmino, C.R. Globalization and fruit fly invasion and expansion: The medfly paradigm. Genetica 2007, 131, 1-9. [CrossRef]

42. Carey, J.R.; Liedo, P.; Harshman, L.; Zhang, Y.; Müller, H.G.; Partridge, L.; Wang, J.L. A mortality cost of virginity at older ages in female Mediterranean fruit flies. Exp. Gerontol. 2002, 37, 507-512. [CrossRef]

43. Robinson, A.S. Mutations and their use in insect control. Mutat. Res. 2002, 511, 113-132. [CrossRef]

44. Light, D.M.; Jang, E.B.; Dickens, J.C. Electroantennogram responses of the Mediterranean fruit fly, Ceratitis capitata, to a spectrum of plant volatiles. J. Chem. Ecol. 1988, 14, 159-180. [CrossRef] [PubMed]

45. Levinson, H.; Levinson, A.; Muller, K. Influence of some olfactory and optical properties of fruits on host location by the Mediterranean fruit fly (Ceratitis capitataWied.). J. Appl. Entomol. 1990, 109, 44-54. [CrossRef]

46. Light, D.M.; Jang, E.B.; Flath, R.A. Electroantennogram responses of the Mediterranean fruit fly, Ceratitis capitata, to the volatile constituents of nectarines. Entomol. Exp. Appl. 1992, 63, 13-26. [CrossRef]

47. Hernandez, M.M.; Sanz, I.; Adelantado, M.; Ballach, S.; Primo, E. Electroantennogram activity from antennae of Ceratitis capitata (Wied.) to fresh orange airborne volatiles. J. Chem. Ecol. 1996, 22, 1607-1619. [CrossRef]

48. Katsoyannos, B.I.; Kouloussis, N.A.; Papadopoulos, N.T. Response of Ceratitis capitata to Citrus chemicals under semi-natural conditions. Entomol. Exp. Appl. 1997, 82, 181-188. [CrossRef]

49. Shelly, T.E. Exposure to $\alpha$-copaene and $\alpha$-copaene-containing oils enhances mating success of male Mediterranean fruit flies (Diptera: Tephritidae). Ann. Entomol. Soc. Am. 2001, 94, 497-502. [CrossRef]

50. Barry, J.D.; Shelly, T.E.; McInnis, D.O.; Morse, J.G. Potential for reducing overflooding ratios of sterile mediterranean fruit flies (diptera: Tephritidae) with the use of ginger root oil. Fla. Entomol. 2008, 86, 29-33. [CrossRef]

51. Shelly, T.E.; Holler, T.C.; Stewart, J.L. Mating competitiveness of mass-reared males of the mediterranean fruit fly (Diptera: Tephritidae) from eclosion towers. Fla. Entomol. 2006, 89, 380-387. [CrossRef]

52. Shelly, T.E.; Cowan, A.N.; Edu, J.; Pahio, E. Mating success of male mediterranean fruit flies following exposure to two sources of $\alpha$-copaene, manuka oil and mango. Fla. Entomol. 2008, 91, 9-15. [CrossRef]

53. Jang, E.B. Effects of mating and accessory gland injections on olfactory-mediated behavior in the female Mediterranean fruit fly, Ceratitis capitata. J. Insect Physiol. 1995, 41, 705-710. [CrossRef]

54. Jang, E.B. Physiology of mating behavior in Mediterranean fruit fly (Diptera: Tephritidae): Chemoreception and male accessory gland fluids in female post-mating behavior. Fla. Entomol. 2002, 85, 89-93. [CrossRef]

55. Vanickova, L.; do Nascimento, R.R.; Hoskovec, M.; Jezkova, Z.; Brizova, R.; Tomcala, A.; Kalikova, B. Are the wild and laboratory insect populations different in semiochemical emission? The case of the medfly sex pheromone. J. Agric. Food Chem. 2012, 60, 7168-7176. [CrossRef]

56. Crnjar, R.; Scalera, G.; Liscia, A.; Angioy, A.M.; Bigiani, A.; Pietra, P.; Tomassini Barbarossa, I. Morphology and EAG mapping of the antennal olfactory receptors in Dacus oleae. Entomol. Exp. Appl. 1989, 51, 77-85. [CrossRef]

57. Willhoeft, U.; Franz, G. Identification of the sex-determining region of the Ceratitis capitata Y chromosome by deletion mapping. Genetics 1996, 144, 737-745.

58. Solari, P.; Crnjar, R.; Frongia, A.; Sollai, G.; Secci, F.; Spiga, M.; Masala, C.; Liscia, A. Oxaspiropentane derivatives as effective sex pheromone analogues in the gypsy moth: Electrophysiological and behavioral evidence. Chem. Senses 2007, 32, 755-763. [CrossRef]

59. Sollai, G.; Solari, P.; Masala, C.; Crnjar, R.; Liscia, A. Effects of avermectins on olfactory responses of Culicoides imicola (Diptera: Ceratopogonidae). J. Med. Entomol. 2007, 44, 656-659. [CrossRef]

60. Sollai, G.; Solari, P.; Masala, C.; Liscia, A.; Crnjar, R. A K+/H+ P-ATPase transport in the accessory cell membrane of the blowfly taste chemosensilla sustains the transepithelial potential (TEP). J. Comp. Physiol. A 2008, 194, 981-988. [CrossRef] 
61. Sollai, G.; Solari, P.; Corda, V.; Masala, C.; Crnjar, R. The spike generator in the labellar of the blowfly is differentially affected by 4-aminopyridine and 5-hydroxytryptamine. J. Insect Physiol. 2012, 58, 1686-1693. [CrossRef]

62. Stensmyr, M.C.; Larsson, M.C.; Bice, S.; Hansson, B.S. Detection of fruit- and flower-emitted volatiles by olfactory receptor neurons in the plyphagous fruit chafer Pachnoda marginata (Coleoptera: Cetoniinae). J. Comp. Physiol. A 2001, 187, 509-519. [CrossRef] [PubMed]

63. Sollai, G.; Tomassini Barbarossa, I.; Usai, P.; Hummel, T.; Crnjar, R. Association between human olfactory performance and ability to detect single compounds in complex chemical mixtures. Physiol. Behav. 2020, 217, 112820. [CrossRef] [PubMed]

64. Sollai, G.; Tomassini Barbarossa, I.; Masala, C.; Solari, P.; Crnjar, R. Gustatory sensitivity and food acceptance in two phylogenetically closely related Papilionid species: Papilio hospiton and Papilio machaon. PLoS ONE 2014, 9, e100675. [CrossRef] [PubMed]

65. Sollai, G.; Tomassini Barbarossa, I.; Solari, P.; Crnjar, R. Taste discriminating capability to different bitter compounds by the larval styloconic sensilla in the insect herbivore Papilio hospiton (Géné). J. Insect Physiol. 2015, 74, 45-55. [CrossRef]

66. Sollai, G.; Biolchini, M.; Solari, P.; Crnjar, R. Chemosensory basis of larval performance of Papilio hospiton on different host plants. J. Insect Physiol. 2017, 99, 47-57. [CrossRef]

67. Siciliano, P.; Scolari, F.; Gomulski, L.M.; Falchetto, M.; Manni, M.; Gabrieli, P.; Field, L.M.; Zhou, J.-J.; Gasperi, G.; Malacrida, A. Sniffing out chemosensory genes from the Mediterranean fruit fly, Ceratitis capitata. PLoS ONE 2014, 9, e85523. [CrossRef]

68. Jang, E.B.; Light, D.M.; Binder, R.G.; Flath, R.A.; Carvalho, L.A. Electroantennogram response of the Mediterranean fruit fly, Ceratitis capitata, to identified constituents from calling males. Entomol. Exp. Appl. 1989, 50, 7-19. [CrossRef]

69. Demirel, N. Behavior paradigms in the Mediterranean fruit fly, Ceratitis capitata (Weidemann). J. Entomol. 2007, 4, 129-135.

70. Fein, B.L.; Reissig, W.H.; Roelofs, W.L. Identification of apple volatiles attractive to the apple magot, Rhagoletis pomonella. J. Chem. Ecol. 1982, 8, 1473-1487. [CrossRef]

71. Light, D.M.; Jang, E.B. Electroantennogram responses of the oriental fruit fly, Dacus dorsalis to a spectrum of alcohol and aldehyde plant volatiles. Entomol. Exp. Appl. 1987, 45, 55-64. [CrossRef]

72. Huang, A.P.; Bao, X.C.; Liu, B.Y.; Wang, Y.J.; Zhou, L.Y.; Ning, J.; Han, B.Y. Electroantennogram responses of the tea slug moth, Iragoides fasciata to some plant volatiles associated with tea, Camellia Sinensis. J. Insect Sci. 2012, 12, 75. [CrossRef] [PubMed]

73. Visser, J.H. Host Odor perception in phytophagous insects. Annu. Rev. Entomol. 1986, 31, 121-144. [CrossRef]

74. Dicke, M.; van Loon, J.J.A. Multitrophic effects of herbivore-induced plant volatiles in an evolutionary context. Entomol. Exp. Appl. 2000, 97, 237-249. [CrossRef]

75. Arita, L.H.; Kaneshiro, K.Y. Sexual selection and lek behavior in the Mediterranean fruit fly, Ceratitis capitata (Diptera: Tephritidae). Pac. Sci. 1989, 43, 135-143.

76. Eberhard, W. Sexual behavior and sexual selection in the Mediterranean fruit fly, Ceratitis capitata (Dacinae: Ceratitidini). In Fruit Flies (Tephritidae): Phylogeny and Evolution of Behavior; Aluja, M., Norrbom, A., Eds.; CRC Press: Boca Raton, FL, USA, 2000; pp. 457-489.

77. Whittier, T.S.; Kaneshiro, K.Y.; Prescott, L.D. Mating-behavior of Mediterranean fruit flies (Diptera, Tephritidae) in a natural environment. Ann. Entomol. Soc. Am. 1992, 85, 214-218. [CrossRef]

(C) 2020 by the authors. Licensee MDPI, Basel, Switzerland. This article is an open access article distributed under the terms and conditions of the Creative Commons Attribution (CC BY) license (http://creativecommons.org/licenses/by/4.0/). 